\title{
Aneurysmal Fibrous Histiocytoma
}

$\left[\begin{array}{c}\text { Aneurysmal Fibrous Histiocytoma } \\ \text {-Clinico-pathological analysis of } 12 \text { cases- } \\ \text { 有沢 祥子*1 } \\ \text { 池谷田 康彦*1 } \\ \text { 新田悠紀子*1 }\end{array}\right.$

池谷 敏彦*1 原一夫*2

\section{Summary}

Twelve cases of aneurysmal fibrous histiocytoma of the skin, from 7 male and 5 female patients with an age range of 24 65 years (mean : 38.5 years), are described. Anatomical distribution; lower limb/limb girdle (6 cases), upper limb/limb girdle (4 cases) and trunk (2 cases). Lesional size ranged from $0.2 \mathrm{~cm}$ to $6 \mathrm{~cm}$ (mean: $1.5 \mathrm{~cm}$ ). Two patients noticed rapid growth in tumor size as well as tenderness.

Histologically, prominent blood-filled spaces were obserbed in the cellular area of the lesion. The spaces lacked an endothelial lining and were surrounded by the area with prominent deposition of hemosiderin pigments, numerous siderophages, and multinucleated giant cells with hyperchromatic nuclei. In seven cases (58\%), in addition to the cellular area, fibrous area was observed in the periphery of the lesion. We presumed that, in adittion to repeated minor trauma, a mechanical stress to the cellular area from adjacent fibrous area might be another factor in the formation of blood-filled spaces in aneurysmal fibrous histiocytoma.

\section{はじめに}

1981年に Santa Cruz) らが aneurysmal (angiomatoid) fibrous histiocytoma of the skin (以下 AFH と略) と命名した皮膚線維腫の一亜 型は臨床的に通常の皮膚線維腫より大きく，青 色, 黒色, 暗赤色を呈し, 疼痛や急速な増大傾 向がみられるので, 悪性黒色腫, 血管腫, 囊腫 などと誤診されやすい。病理組織学的には，通

*1 Shoko ARISAWA, Yasuhiko TAMADA, Yukiko NITTA, Toshihiko IKEYA：愛知医科大学皮 膚科学教室

*2 Kazuo HARA：愛知医科大学病院病理部
常の皮膚線維腫の一部に，ときには病変の半分 を超す大きな，血管内皮細胞を欠く赤血球に満 たされた空隙がみられ，その周辺にはへモジデ リンの沈着，へモジデリンを食食した組織球, 泡沫細胞等が認められる。

今回著者らは，過去 10 年間に愛知医科大学病 院病理部で診断された皮膚線維腫152例中の 5 例 $(3.3 \%)$ ，他施設よりコンサルテーション された症例の 7 例の計12例の $\mathrm{AFH}$ につき臨床 像と病理組織学的所見を検討し, さらに空陌が 生ずる機序について考察した。

診断基準：1995年のCalonje ら 2)の報告に従 い, 通常の皮膚線維腫の病変内に, artifactual clefts 惑いは cavernous vascular channelsに 似た blood-filled spaces を持つこととした。 
臨床像：12例の内訳は，男性 7 例，女性 5 例 で, 年齢は24歳から65歳で平均 38.5 歳（図 1 )。 発症部位は躯幹で 2 例，上肢に 4 例，下肢に 6 例であった(表 1 )。大きさは, 直径 $2 \mathrm{~mm}$ から 最大径 $60 \mathrm{~mm}$ まであり, 平均 $15 \mathrm{~mm}$ である。直 径 $60 \mathrm{~mm}$ のものは粗大顆粒状を呈し(図 2 ), 有 茎性結節を呈するものもあった。色調は暗赤褐 色を呈するものが多く, 鮮紅色が 1 例あった。 また 2 例は急激に増大し圧痛を伴い，1例は易 出血性であった。

病理組織所見：全例に共通した所見は，表皮 は軽度の角質増生と, 有棘層の肥厚を示す。真 皮網状層全層に境界がやや不明瞭な紡錘形細胞 の増殖する病変があり，その中に大小の不規則 な形の赤血球を入れた空㭞 (blood-filled space) を持つ（図 3 )。強拡大像では, bloodfilled spaces 辺縁には血管内皮を欠くことがわ

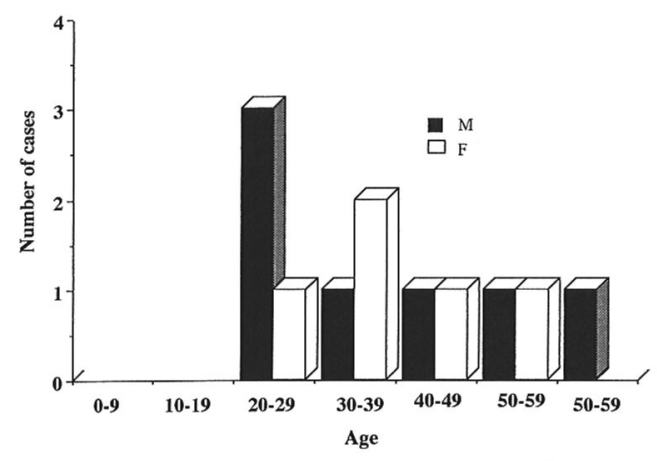

図 1.Age and sex distribution in 12 cases of AFH

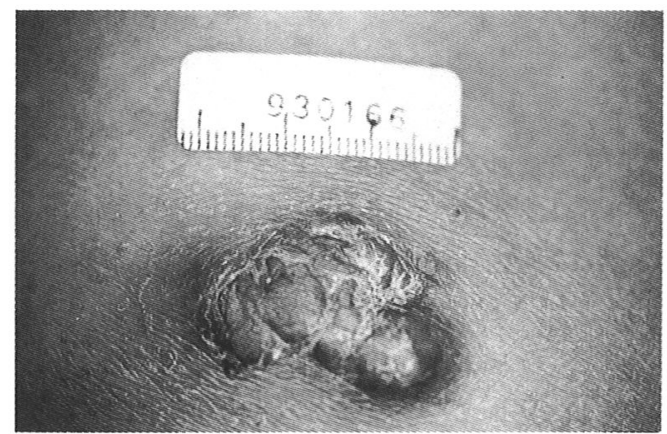

図 2. Clinical feature of $\mathrm{AFH}$ of $6 \mathrm{~cm}$ in diameter
かる(図 4)。この空隙の内外では全例に出血が みられ, 周囲には, homosiderin の沈着, siderophagesを認めた。また elastica van Gieson 染 色で, 弾力線維は腫瘍内に殆ど認められなかっ た。

通常の皮膚線維腫と異なる所見としては，10 例で左右の非対称性があり，内 1 例では多結節 性病変であった。また 7 例に於いて, 病変の辺 縁部には膠原線維が豊富で細胞密度の低い fibrous area があり, 中央寄には膠原線維がそ しく細胞密度の高い cellular area が認められ る二層性パターンが明らかであった。 AFH で 特徽的に認められる blood-filled spaces は主 に cellular area の内部で, かつ fibrous area と の境界部近くに認められた。二層性を示さない 5 症例は, cellular area で占められていた。

$\mathrm{AFH} の$ 構成細胞は fibrous area は主に紡錘 形細胞であった。一方， cellular area では，短 紡錘形細胞に加え類上皮様細胞が認められ，多 数の小血管の増生を伴っていた。泡沫状の多核 巨細胞，泡沫状マクロファージ，リンパ球等を 種々の割合に認めた (図 5 )。Cellular areaに

表 1. Anatomical distribution of 12 cases of $\mathrm{AFH}$

\section{Anatomical distribution}

Lower limb/limb girdle

$\begin{array}{ll}\text { buttock } & 2 \\ \text { thight/knee } & 3 \\ \text { foot } & 1\end{array}$

Upper limb/limb girdle upper arm/elbow 1

$\begin{array}{ll}\text { forearm } & 2 \\ \text { hand } & 1\end{array}$

Trunk

$\begin{array}{ll}\text { chest } & 1 \\ \text { back } & 1\end{array}$




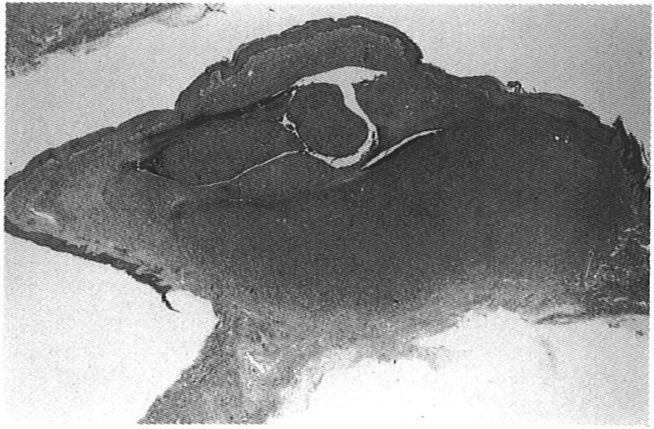

図3. Overview of the pedunculated AFH. A large fissure-like blood-filled spaces are found in the cellular area. Fibrous area is seen in the periphery of the lesion. (H.E. $\times$ 15)

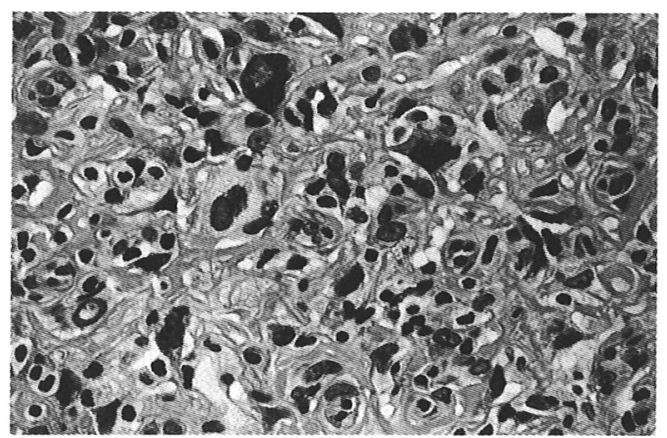

図 5. Multinucleated giant cells with hyperchromatic nuclei, foamy macrophages and lymphocytes are observed in the cellular area. (H.E.)

は, 核型不整, 核クロマチンの増量などの細胞 異型を 8 例 $(66.7 \%)$ にみとめたが，核分裂像 は，4例 (33.3\%) で1〜2 個/10hpf 程度であ った。異常核分裂像は認めなかった。

免疫組織学的所見：8症例で検討した。紡錘 形あるいは類上皮様の腫瘍細胞はFactor XIIIa， CD34，デスミンに陰性。4 例で腫瘍の fibrous areaの一部に alpha-smooth muscle actinが 陽性であった。UEA-1染色でみると, bloodfilled spaces 内面には UEA-1陽性の血管内皮 は殆ど認められず, H-E 染色標本での所見と一 致した。また, cellular area では増生していた 小血管壁には, alpha-smooth muscle actin が ごく一部にのみ認められた(図 6 )。一方 fibrous

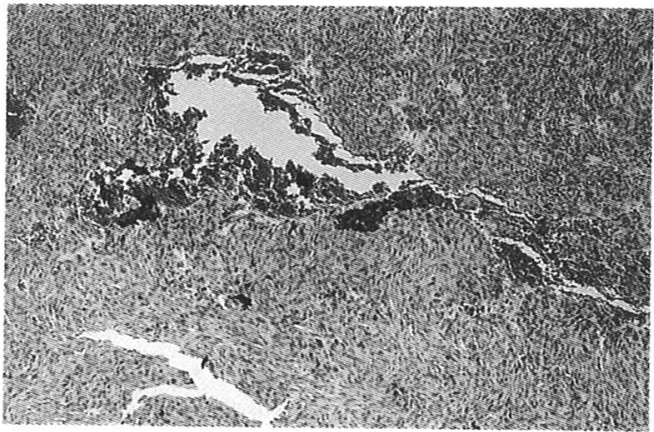

図 4. The blood-filled spaces have no endothelial lining. (H.E.)

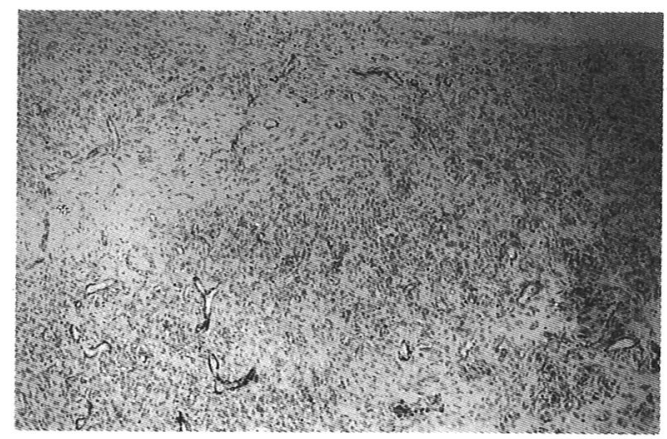

図 6. In the cellular area, a few alpha-smooth muscle actin positive vessels are seen. (ABC method)

area では血管増生が少ないが，その血管は UEA-1, alpha-smooth muscle actin にて同程 度に陽性であった。

\section{考 察}

Aneurysmal fibrous histiocytoma (AFH) は皮膚線維腫の比較的稀な亜型で, Santa Cruz ら ${ }^{1)}$ は皮膚線維腫のうち8.7\%, Caronje ら ${ }^{2)}$ は $1.7 \%$, 堀木ら ${ }^{3)}\left(9.9 \%\right.$, 勝俣ら ${ }^{4)} 2.6 \%$ と報告 している。我々の症例は 152 例中 5 例 $(3.3 \%)$ であった。四肢に好発，通常の皮䖉線維腫に比 して, サイズが大きいこと, 赤色〜黒色調を呈 


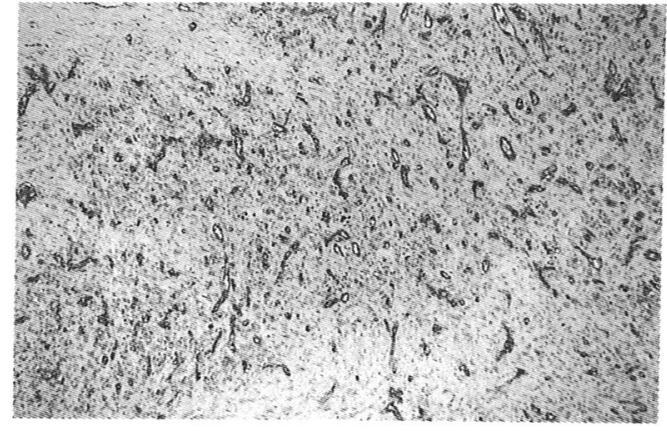

図 7. UEA-1 stainig clearly demonstrated the presence of numerous small vessels in the cellular area. (ABC method)

すること，急激に大きくなること等が臨床的な 特徵として報告されている ${ }^{12)}$ 。我々の検討で も，発症部位は四肢が10例 (83\%)，大きさは平 均 $15 \mathrm{~mm}$ で，暗赤色から褐色調を呈し，2例で は急激な増大が見られた。臨床的には悪性黒色 腫等の悪性腫瘍と誤診されることが問題とな る。我々の症例での臨床診断は，陸起性皮膚線 維肉腫が 1 例，血管腫が 3 例，粉瘤が 1 例，㓔 痕 1 例，皮膚線維腫が 4 例であった。

病理組織学的には，皮膚線維腫の病変内に， 血管内皮を欠く, blood-filled space を持つこ と，また増生細胞に紡錘形，類上皮細胞様，泡 沫状マクロファージ，多核巨細胞等の多様性が あり，特に多型性を示すことが，本腫瘍の特徵 である。また, 今回の我々の検討で，12例中 7 例 $(58 \%)$ ），通常の皮膚線維腫にみられる fibrous area と小血管が増生した細胞密度の高 い cellular area の二層性パターンを認めた。そ のうち 5 例は fibrous area が腫瘍辺縁で, cellular area は fibrous areaに取り囲まれる様に, 2 例は両者が複雑にいり込むような形でみられ た。免疫組織化学的に, UEA-1染色でみると cellular area 内は小血管が多数増生するが
(図 7 )，その小血管は smooth muscle actin が 陰性のものが多かった(図 6)。したがってそれ らは平滑筋を持たない脆弱な血管といえる。

Blood-filled spacesが生ずる機序として，

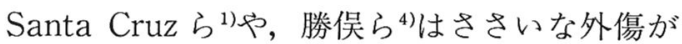
何度も起こり, 膠原線維や弾力線維が少ない細 胞の密な部分（cellular area）に血管よりの微 少出血が続き，血液が溜まる事により生ずると 推論している。我々は(1) cellular areaに於ける 膠原線維, 弾力線維の㞯しさ，(2) cellular area に於ける平滑筋を欠く脆弱な小血管の増生等の ほかに(3)腫瘍の二層性パターンに注目した。二 層性パターンを示す $\mathrm{AFH}$ においては皮膚線維 腫の cellular area は時間の経過と共にその辺 縁に線維化が進み fibrous area が形成される と思われる。その二つの領域の間には質的な違 いがあるために，微小な外傷が繰り返されると cellular area と fibrous area の境界部に歪が 生じ，出血をきたし，それが癒合し大きな血液 を入れた裂吵を生じた可能性を考えた。Bloodfilled spaces が二層性の境界部に近い cellular areaにあることもこの推定を支持する所見と 考えられる。

\section{文献}

1 ) Santa, Cruz, D.J., Kyriakos, M.: Aneurysmal ('angiomatoid') fibrous histiocytoma. Am. J. Dermatopathol, 47 : 467-471, 1986.

2 ) Calonje. E., Fletcher, C.D.M, : Aneurysmal benign fibrous histiocytoma: clinicopathological analysis of 40 cases of a tumor frequntly misdiagnosed as a vascular neoplasm. Histopathology, 26 : 323-331, 1995.

3 ）堀木聡, 堀尾武, 朝田康夫：Aneurysmal fibrous histiocytomaの一例と皮膚線維腫の統計的考察. 皮膚，35：505-509，1993。

4 ) 勝俣道夫, 三瓶清恵: Aneurysmal (Angiomatoid) fibrous histiocytoma of the skin. 皮 膚臨床，28(3)：295-301，1986. 